\title{
Protecting Child Health by Preventing School Packed Lunch Related Food Borne Illnesses: A Qualitative Study of Parents Lunch Box Related Practices
}

\author{
Sloney Sachar* and Sonika Sharma
}

Punjab Agricultural University Ludhiana, Punjab, India

*Corresponding author

\section{A B S T R A C T}

\section{Keywords}

Food borne diseases, Lunch box related practices, Packaging material, Time of cleaning, Storage of lunch box

\section{Article Info}

Accepted:

15 July 2019

Available Online:

10 August 2019
A study was conducted to assess the practices of the respondents related to packing, storage and cleaning in context of children's packed lunch boxes and to find out the correlation of these practices with the food borne disease incidence of children. Parents of 480 children (4-6 years) from Ludhiana and Patiala district of Punjab from both urban and rural areas were administered a questionnaire to elicit the information regarding choice of packaging material, choice of time to clean lunch boxes, usage of material and kind of lunch boxes, preferred medium for cleaning lunch boxes and attributes affecting purchase of lunch box. The respondents were asked to rate their practices in a rating scale of 5-1 and the results revealed that regarding the choice of packaging material it was seen that in both urban and rural respondents aluminium foil was the most preferred packaging material with the mean score of 3.88. This was followed by cloth napkin (mean score: 2.58), paper napkin (mean score: 2.17 ) and newspaper (mean score: 1.28). Most of the respondents preferred evening time to clean lunch boxes with mean score of 3.37 . Food grade plastic was the most preferred material with the mean score of 3.9 preferably used by the urban respondents, followed by the stainless steel (3.40) and Low grade plastic (1.48). The results revealed that the practice of use of aluminium foil $(\mathrm{p}<0.05)$, cleaning lunch boxes with hot water $(\mathrm{p}<0.01)$, soft sponge and air dry method, cleaning lunch boxes immediately after child came back from school showed a significant negative correlation with the disease incidence.

\section{Introduction}

Packed lunches provide a sole medium as they unite the school, parent and student. Also for some families it is important to provide packed lunches as these were thought to be inexpensive than school meals (Griffin and Barker 2008). The greater number of foodborne disease incidences have been associated with commercial cuisine places like canteens, hotels, restaurants, mobile caterers and public houses, it is also well known that the household surroundings makes a major but frequent under-reported contribution to food borne diseases (Hughes et al., 2007). Practices of parents related to packing their children's lunchboxes have potential effects on the packed food temperature and if steps were not taken this may cause foodborne illness (Almansour et al., 2011). Parental and the community education must be focusing on techniques or practices to pack lunches which 
permit the food to stay in the secure temperature region to prevent foodborne diseases (Almansour et al., 2011). To consider the numerous factors related to parental food packing behavior involving child likings and restrictions faced by families is an important further research step. Programs to implement welfare policies of school are needed to team up with parents to enhance the quality of foods in lunch boxes taken from home to eaten at school. Food safety programs should be designed not only to increase knowledge about food safety, including left-over food handling, but also to emphasize the importance of adopting safe food handling practices (Roberts et al., 2008). Additionally, schools are encouraged to involve parents and students as key stakeholders in ensuring a healthy school environment (USDA-FNS, 2012) and parents have previously shown interest in partnering with schools to improve lunches (Sweitzer et al., 2011). At last, both rural and urban school districts, and varied population of school children should be included in upcoming studies or researches (Hubbard et al., 2014). The parents of children are more likely to modify behavior when the change would benefit their children (U. S. Department of Agriculture, 2005). Parents and caregivers need to be educated about safe storage and handling of bag lunches. The knowledge and practices of mothers of children indicate a need for food safety messages. Food safety messages must encourage food safety practices benefiting the health of children and preventing terrible illness or death (Kwun et al., 2011).

\section{Materials and Methods}

The parents of 480 children (4-6 yrs) from Kindergarten sections were selected from six private schools of Ludhiana district and six private schools of Patiala district from Punjab (India) both from urban and rural areas. For collecting data a pre-structured non-disguised questionnaire was prepared. An inventory to assess knowledge was prepared from available secondary sources as well as expert advice. Questions were framed to elicit the information on the practices related to packing, storage and cleaning in context of lunch boxes. The questionnaire was pretested by undertaking a pilot study involving ten stakeholders, to ensure the validity of questionnaire. This sample size was excluded from the final sample. Data was collected by personally administering the questionnaire to the stakeholders regarding their choice of packaging material, choice of time to clean lunch boxes, usage of material and kind of lunch boxes, preferred medium for cleaning lunch boxes on a rating scale of 5-1.Data was collected from the parents on the incidence of food borne diseases among the children for the past one year across the different seasons as part of the questionnaire. Data obtained from the survey was analyzed using various statistical tools such as mean, standard deviation, ANOVA, $\mathrm{t}$ - test, correlation and Ztest.

\section{Results and Discussion}

Respondents were enquired about their choice regarding various practices and were asked to rate these from always to never. For analyzing the data thus obtained, the response of always was given 5 scores and the response of never was given 1 score. Mean scores of the respondents have been shown in table 4.16.

\section{Packaging material}

The respondents were enquired about the choice of packaging material they preferred to pack lunch of the children on the basis of the background. It can be seen from the Table 1 that in both urban and rural respondents aluminium foil is the most preferred packaging material with the mean score of 3.88 and the higher mean scores were given 
by the urban respondents. This was followed by cloth napkin (mean score: 2.58) mostly used by rural respondents. Further data revealed that paper napkin (mean score: 2.17 ) is more used by rural respondents (mean score: 2.28) as compared to the urban respondents (mean score: 2.07).The least preference was given to the paper and newspaper which is more used by the rural respondents with the mean score of 2.17 and 1.45 showing a significant difference $(\mathrm{p}<0.01)$ between the mean scores given by the urban respondents.

Overall results showed that paper napkin, newspaper, cloth napkin were mostly preferred by the rural respondents while aluminium foil is mostly used by the urban respondents. Emily (2013) reported that respondents had significant preference for certain packaging materials based on functionality and credence attributes, and perceived certain materials as more suitable for certain food products.

The respondents were enquired about the choice of packaging material on the basis of their educational qualification. It can be seen from the Table 2 that educational qualification of the respondents affects the choice of packaging material used to pack the lunch of children. Data revealed that higher the educational qualification better was the choice of packaging material. It can be seen that graduates mostly preferred to use aluminium foil and paper napkin with the mean scores of 4.00 and 2.23. The respondents studied upto $12^{\text {th }}$ standard practiced to use paper, cloth napkin and newspaper with the mean scores of 2.28, 2.86 and 1.47 showing a significant difference among the mean scores given by other counterparts.

It can be seen from the Table 3 that age and income of the respondents significantly affect the choice of packaging material. Data revealed that respondents belonging to the young age group of 20-29 years, having income of > 5 lakhs, belonging to nuclear families mostly preferred to use aluminium foil. The study conducted by Ogba and Johnson (2010) shows that packaging does affect the product preferences of children. Also, children are particularly interested in influencing the purchase of unhealthy foods. However, parents within the study claimed that they did not entertain their children's requests for the purchase of unhealthy food. Also data showed that age and income of the respondents had significant effect on the choice of packaging material.

\section{Time to clean lunch boxes}

The respondents were asked about their choice of time to clean the children's lunch boxes is shown in Table 4. It can be observed from the Table that most of the respondents preferred evening time to clean lunch boxes with mean score of 3.37 and mostly preferred by the rural respondents showing a significant $(\mathrm{p}<0.01)$ difference in the mean scores, followed by the practice of cleaning lunchboxes immediately after child came back from school with the mean score of 3.16 especially in the urban respondents having a significant $(\mathrm{p}<0.05)$ difference in the mean scores given by urban and rural respondents. This practice of cleaning lunch boxes immediately when the child came back home was considered as a better practices than other timing of cleaning as the microbial load on lunch box was the mininmum at this time. The practice of cleaning lunch boxes during night time was observed mostly in the rural respondents with the mean score of 2.90 and showed a significant difference among mean scores given by respondents segregated on the basis of background $(\mathrm{p}<0.05)$. The practice of cleaning lunch boxes early morning was the least preferred choice of time with mean score of 1.26. This timing of cleaning also lead to 
maximum microbial load with the presence of E. coli, Staphylococcus aureus and Salmonella spp. The study conducted by Silva et al., (2010) showed the importance of good cleaning and sanitization procedures to prevent bacterial adherence and biofilm formation. To address potential crosscontamination by kitchen utensils in the home Erickson et al., (2015) conducted a study to determine the extent to which the use of a knife or grater on fresh produce would lead to the utensil's contamination with Escherichia coli $\mathrm{O} 157: \mathrm{H} 7$ or Salmonella enteric and reported the subsequent contamination of 7 produce items processed with the contaminated utensils. The results highlighted the necessity of proper sanitization of utensils when used in preparation of raw produce.

The choice of time to clean lunch boxes was studied on the basis of educational qualification of the respondents. It can be observed from the Table 5 that the practice of cleaning lunchboxes immediately after child came back from school was mostly preferred by the postgraduates (mean score: 3.57 ) with a significant $(\mathrm{p}<0.01)$ difference in the mean scores showing that better the qualification better the choice of timing that reduced the incidence of contamination in lunch boxes.

Data further revealed that graduates and postgraduates preferred to clean lunch boxes during evening and early morning while the respondents studied upto $12^{\text {th }}$ standard preferred to clean lunch boxes during night with a mean score of 3.02. Data showed that higher the educational qualification better the choice of time to clean lunch boxes (immediately after child came back home, evening, night and lastly early morning with the higher microbial load). As more time taken to clean the lunch box could lead to building up the microbial load in the tiffin box. According to Ahmed (2015) educational level of mothers was a factor influencing the level of mothers' knowledge about food poisoning and $37.2 \%$ of them mentioned contaminated utensils as a possible cause of food poisoning.

The respondents were further segregated on the basis of age, income and type of family, so based on these parameters they were enquired about the choice of time to clean lunch boxes. It can be observed from the Table 6 that the respondents belonging to the age group of 3039 , having joint families and having income category of 2-5 lakhs preferred to clean the lunch boxes immediately after child came back from school. The study conducted by Silva et al., (2010) showed the importance of good cleaning and sanitization procedures to prevent bacterial adherence and biofilm formation.

\section{Preferred medium for cleaning of lunch boxes}

The respondents were enquired about the practices related to cleaning and drying of lunch boxes. It can be seen from the Table 7 that mostly rural respondents used cold water to clean lunch boxes with overall mean score of 3.43 as compared to hot water (mean score:3.32)preferably used by the urban respondents (mean score: 3.57 ) that showed a significant $(\mathrm{p}<0.01)$ difference in the mean scores. Hot water is a prefered medium to clean Lunch box as it lowered the microbial load on lunch box. The practice of using detergent was observed in both urban and rural respondents with mean score of 3.64.Further soft sponge (mean score: 4.28) was more preferred by the rural respondents to wipe lunch boxes as compared to the cloth (mean score: 3.43 ) mostly preferred by the urban respondents (mean score: 3.44). The practice of air drying the lunch box is mostly observed in the rural respondents with overall mean score of 3.59 showing a significant $(\mathrm{p}<0.01)$ difference in the mean scores given by the urban and rural respondents. 
Table.1 Choice of packaging material on basis of Background

\begin{tabular}{|l|c|c|c|c|c|}
\hline $\begin{array}{l}\text { Choice of } \\
\text { packaging } \\
\text { material }\end{array}$ & $\begin{array}{c}\text { Total } \\
(\mathbf{n = 4 8 0})\end{array}$ & \multirow{2}{*}{ Z- value } & $\begin{array}{c}\text { Urban } \\
(\mathbf{n = 2 4 0})\end{array}$ & \multicolumn{1}{c|}{$\begin{array}{c}\text { Rural } \\
(\mathbf{n = 2 4 0})\end{array}$} & \multirow{2}{*}{ t- value (P VALUE) } \\
\cline { 2 - 4 } & Mean \pm SD & & Mean \pm SD & Mean \pm SD & \\
\hline Paper & $1.78 \pm 1.27$ & $-20.89 * *$ & $1.38 \pm .84$ & $2.17 \pm 1.49$ & $-7.17 * *(<0.0001)$ \\
\hline Aluminium foil & $3.88 \pm 1.49$ & $12.90 * *$ & $3.95 \pm 1.59$ & $3.80 \pm 1.38$ & $1.12(0.25)$ \\
\hline Cloth Napkin & $2.58 \pm 1.68$ & $-5.35 * *$ & $2.52 \pm 1.67$ & $2.65 \pm 1.68$ & $-0.84(0.40)$ \\
\hline Paper Napkin & $2.17 \pm 1.50$ & $-11.94 * *$ & $2.07 \pm 1.50$ & $2.28 \pm 1.50$ & $-1.51(0.13)$ \\
\hline Newspaper & $1.28 \pm 0.90$ & $-41.24 * *$ & $1.12 \pm .50$ & $1.45 \pm 1.16$ & $-3.97 * *(<0.0001)$ \\
\hline
\end{tabular}

** significant at $1 \%$ level

Table.2 Choice of Packaging material on basis of educational Qualification

\begin{tabular}{|c|c|c|c|}
\hline Choice of packaging material & Category & Mean \pm SD & F- Value (p value) \\
\hline \multirow[t]{3}{*}{ Paper } & Upto $12^{\text {th }}$ standard & $2.28^{\mathrm{a}} \pm 1.52$ & \multirow{3}{*}{$17.73 * *(<0.0001)$} \\
\hline & Graduation & $1.54^{\mathrm{b}} \pm 1.03$ & \\
\hline & Postgraduation & $1.58^{b} \pm 1.16$ & \\
\hline \multirow[t]{3}{*}{ Aluminium foil } & Upto $12^{\text {th }}$ standard & $3.69^{\mathrm{a}} \pm 1.20$ & \multirow[t]{3}{*}{$1.419(0.24)$} \\
\hline & Graduation & $4.00^{a} \pm 1.57$ & \\
\hline & Postgraduation & $3.89^{\mathrm{a}} \pm 1.65$ & \\
\hline \multirow[t]{3}{*}{ Cloth Napkin } & Upto $12^{\text {th }}$ standard & $2.86^{\mathrm{a}} \pm 1.79$ & \multirow[t]{3}{*}{$3.94 *(0.02)$} \\
\hline & Graduation & $2.37^{\mathrm{bc}} \pm 1.48$ & \\
\hline & Postgraduation & $2.65^{\mathrm{ac}} \pm 1.83$ & \\
\hline \multirow[t]{3}{*}{ Paper Napkin } & Upto $12^{\text {th }}$ standard & $2.13^{\mathrm{a}} \pm 1.34$ & \multirow[t]{3}{*}{$.205(0.81)$} \\
\hline & Graduation & $2.23^{\mathrm{a}} \pm 1.51$ & \\
\hline & Postgraduation & $2.19^{\mathrm{a}} \pm 1.68$ & \\
\hline \multirow[t]{3}{*}{ Newspaper } & Upto $12^{\text {th }}$ standard & $1.47^{\mathrm{a}} \pm 1.15$ & \multirow[t]{3}{*}{$4.56^{*}(0.01)$} \\
\hline & Graduation & $1.21^{\mathrm{b}} \pm 0.75$ & \\
\hline & Postgraduation & $1.18^{\mathrm{b}} \pm 0.79$ & \\
\hline
\end{tabular}

** significant at $1 \%$ level

* significant at $5 \%$ level

Table.3 Choice of packaging material on basis of various parameters

\begin{tabular}{|l|c|c|c|}
\hline Choice of Packaging material & Age & Income & Type of family \\
\cline { 2 - 4 } & F- Value & F- Value & t- Value \\
\hline Paper & $0.78(0.45)$ & $27.22^{* *}(<0.0001)$ & $1.66(0.09)$ \\
\hline Aluminium foil & $2.90(0.05)$ & $3.22^{*}(0.04)$ & $-1.71(0.08)$ \\
\hline Cloth napkin & $0.24(0.78)$ & $4.26 *(0.01)$ & $1.60(0.11)$ \\
\hline Paper Napkin & $3.31 *(0.03)$ & $2.59(0.07)$ & $-0.91(0.35)$ \\
\hline Newspaper & $6.84^{* *}(<0.0001)$ & $6.48 * *(<0.0001)$ & $-0.04(0.96)$ \\
\hline
\end{tabular}

Values in cells are F- value/ t- value with p-value in parenthesis

** significant at $1 \%$ level

* significant at $5 \%$ level 
Table.4 Time of cleaning lunch boxes on basis of background

\begin{tabular}{|c|c|c|c|c|c|}
\hline \multirow[t]{2}{*}{$\begin{array}{l}\text { Time of cleaning } \\
\text { lunch boxes }\end{array}$} & $\begin{array}{c}\text { Total } \\
(n=480)\end{array}$ & $\begin{array}{c}\text { z- } \\
\text { value }\end{array}$ & $\begin{array}{c}\operatorname{Urban}(n= \\
240)\end{array}$ & $\begin{array}{c}\text { Rural } \\
(n=240)\end{array}$ & \multirow[t]{2}{*}{ t- value } \\
\hline & Mean \pm SD & & Mean \pm SD & Mean \pm SD & \\
\hline $\begin{array}{l}\text { Immediately after } \\
\text { child came back } \\
\text { from school }\end{array}$ & $3.16 \pm 1.60$ & $2.23 *$ & $3.52 \pm 1.55$ & $3.22 \pm 1.63$ & $2.02 *(0.043)$ \\
\hline Evening & $3.37 \pm 1.63$ & $5.15 * *$ & $2.94 \pm 1.63$ & $3.39 \pm 1.61$ & $-3.03 * *(0.003)$ \\
\hline Night & $2.90 \pm 1.47$ & $-1.38^{\mathrm{NS}}$ & $2.67 \pm 1.47$ & $3.14 \pm 1.44$ & $-3.53 * *(<0.0001)$ \\
\hline Early morning & $1.26 \pm 0.74$ & $-51.0 * *$ & $1.31 \pm 0.75$ & $1.22 \pm 0.75$ & $1.29(0.197)$ \\
\hline
\end{tabular}

Table.5 Time of cleaning lunch boxes on basis of Educational Qualification

\begin{tabular}{|c|c|c|c|}
\hline Time of cleaning lunch boxes & Category & Mean \pm SD & F Value (p value) \\
\hline \multirow{3}{*}{$\begin{array}{l}\text { Immediately after child came } \\
\text { back from school }\end{array}$} & Upto $12^{\text {th }}$ standard & $3.00^{\mathrm{a}} \pm 1.71$ & \multirow[t]{3}{*}{$5.84 * *(<0.001)$} \\
\hline & Graduation & $3.52^{b} \pm 1.54$ & \\
\hline & Postgraduation & $3.57^{\mathrm{b}} \pm 1.49$ & \\
\hline \multirow[t]{3}{*}{ Evening } & Upto $12^{\text {th }}$ standard & $3.10^{\mathrm{a}} \pm 1.67$ & \multirow[t]{3}{*}{$0.85(0.42)$} \\
\hline & Graduation & $3.12^{\mathrm{a}} \pm 1.65$ & \\
\hline & Postgraduation & $3.34^{\mathrm{a}} \pm 1.55$ & \\
\hline \multirow[t]{3}{*}{ Night } & Upto $12^{\text {th }}$ standard & $3.02^{\mathrm{a}} \pm 1.54$ & \multirow[t]{3}{*}{$1.02(0.36)$} \\
\hline & Graduation & $2.90^{\mathrm{a}} \pm 1.40$ & \\
\hline & Postgraduation & $2.75^{\mathrm{a}} \pm 1.53$ & \\
\hline \multirow[t]{3}{*}{ Early morning } & Upto $12^{\text {th }}$ standard & $1.26^{\mathrm{a}} \pm 0.87$ & \multirow[t]{3}{*}{$2.03(0.13)$} \\
\hline & Graduation & $1.32^{\mathrm{a}} \pm 0.69$ & \\
\hline & Postgraduation & $1.15^{\mathrm{a}} \pm 0.62$ & \\
\hline
\end{tabular}

Mean compared against mid point of the scale i.e 3

** significant at $1 \%$ level

Table.6 Time of cleaning lunch boxes on basis of various parameters

\begin{tabular}{|l|c|c|c|}
\hline Time of cleaning lunch boxes & Age & Income & Type of family \\
\cline { 2 - 4 } & F- Value & F- Value & t- Value \\
\hline $\begin{array}{l}\text { Immediately after child came } \\
\text { back from school }\end{array}$ & $5.59 * *(<0.0001)$ & $1.86(0.15)$ & $-1.59(0.110)$ \\
\hline Evening & $1.46(0.23)$ & $0.91(0.40)$ & $1.34(0.180)$ \\
\hline Night & $0.22(0.80)$ & $0.84(0.43)$ & $0.78(0.436)$ \\
\hline Early morning & $0.67(0.50)$ & $1.76(0.17)$ & $1.01(0.309)$ \\
\hline
\end{tabular}

Values in cells are F- value/ $\mathrm{t}$ - value with p-value in parenthesis

** significant at $1 \%$ level 
Table.7 Preferred medium for cleaning of lunch boxes: Comparison on basis of background

\begin{tabular}{|l|c|c|c|c|c|}
\hline $\begin{array}{l}\text { Medium of Cleaning } \\
\text { \& Drying }\end{array}$ & $\begin{array}{c}\text { Total } \\
(\mathbf{n = 4 8 0})\end{array}$ & Z-value & $\begin{array}{c}\text { Urban(n= } \\
\mathbf{2 4 0})\end{array}$ & $\begin{array}{c}\text { Rural } \\
(\mathbf{n = 2 4 0})\end{array}$ & $\begin{array}{c}\text { t- value(p } \\
\text { value) }\end{array}$ \\
\cline { 2 - 4 } & Mean \pm SD & & Mean \pm SD & Mean \pm SD & \\
\hline Hot water & $3.32 \pm 1.34$ & $5.31^{* *}$ & $3.57 \pm 1.23$ & $3.07 \pm 1.40$ & 4.16 \\
& & & & & $* *(<0.0001)$ \\
\hline Cold water & $3.43 \pm 1.60$ & $6.01^{* *}$ & $3.33 \pm 1.59$ & $3.54 \pm 1.59$ & $-1.45(0.14)$ \\
\hline Detergent & $3.64 \pm 1.70$ & $8.31^{* *}$ & $3.63 \pm 1.67$ & $3.66 \pm 1.74$ & $-0.18(0.85)$ \\
\hline Soft sponge (To wipe) & $4.28 \pm 1.33$ & $21.01^{* *}$ & $4.22 \pm 1.35$ & $4.34 \pm 1.31$ & $-0.99(0.32)$ \\
\hline Cloth (To wipe) & $3.43 \pm 1.64$ & $5.78^{* *}$ & $3.44 \pm 1.65$ & $3.42 \pm 1.62$ & $-0.11(0.91)$ \\
\hline Air dry & $3.59 \pm 1.67$ & $7.75^{* *}$ & $3.32 \pm 1.71$ & $3.86 \pm 1.58$ & -3.59 \\
& & & & & $* *(<0.0001)$ \\
\hline
\end{tabular}

** significant at $1 \%$ level

Table.8 Preferred medium for cleaning of lunch boxes: Comparison on basis of Educational Qualification

\begin{tabular}{|c|c|c|c|}
\hline $\begin{array}{l}\text { Medium of Cleaning \& } \\
\text { Drying }\end{array}$ & Category & Mean \pm SD & F value (p value) \\
\hline \multirow[t]{3}{*}{ Hot water } & Upto $12^{\text {th }}$ standard & $3.54^{\mathrm{a}} \pm 1.50$ & \multirow[t]{3}{*}{$4.48^{*}(0.01)$} \\
\hline & Graduation & $3.32^{\mathrm{ac}} \pm 1.23$ & \\
\hline & Postgraduation & $3.03^{b c} \pm 1.30$ & \\
\hline \multirow[t]{3}{*}{ Cold water } & Upto $12^{\text {th }}$ standard & $2.94^{\mathrm{a}} \pm 1.73$ & \multirow[t]{3}{*}{$12.94 * *(<0.0001)$} \\
\hline & Graduation & $3.53^{b} \pm 1.55$ & \\
\hline & Postgraduation & $3.91^{b} \pm 1.30$ & \\
\hline \multirow[t]{3}{*}{ Detergent } & Upto $12^{\text {th }}$ standard & $3.56^{\mathrm{a}} \pm 1.83$ & \multirow[t]{3}{*}{$9.13 * *(<0.0001)$} \\
\hline & Graduation & $3.95^{\mathrm{ab}} \pm 1.50$ & \\
\hline & Postgraduation & $3.13^{\mathrm{ac}} \pm 1.79$ & \\
\hline \multirow{3}{*}{ Soft sponge (To wipe) } & Upto $12^{\text {th }}$ standard & $4.23^{\mathrm{a}} \pm 1.33$ & \multirow[t]{3}{*}{$2.10(0.12)$} \\
\hline & Graduation & $4.20^{\mathrm{a}} \pm 1.44$ & \\
\hline & Postgraduation & $4.50^{\mathrm{a}} \pm 1.07$ & \\
\hline \multirow[t]{3}{*}{ Cloth (To wipe) } & Upto $12^{\text {th }}$ standard & $3.87^{\mathrm{a}} \pm 1.53$ & \multirow[t]{3}{*}{$7.87 * *(<0.0001)$} \\
\hline & Graduation & $3.25^{\mathrm{b}} \pm 1.57$ & \\
\hline & Postgraduation & $3.20^{\mathrm{b}} \pm 1.80$ & \\
\hline \multirow[t]{3}{*}{ Air dry } & Upto $12^{\text {th }}$ standard & $3.95^{\mathrm{a}} \pm 1.63$ & \multirow[t]{3}{*}{$8.64 * *(<0.0001)$} \\
\hline & Graduation & $3.59^{\mathrm{a}} \pm 1.57$ & \\
\hline & Postgraduation & $3.09^{b} \pm 1.78$ & \\
\hline
\end{tabular}


Table.9 Preferred medium for cleaning of lunch boxes: Comparison on basis of various parameters

\begin{tabular}{|l|c|c|c|}
\hline \multirow{2}{*}{ Medium of Cleaning \& Drying } & Age & Income & Type f family \\
\cline { 2 - 4 } & F- Value & F- Value & t- Value \\
\hline Hot water & $1.02(0.36)$ & $13.65 * *(<0.0001)$ & $2.98 * *(0.003)$ \\
\hline Dold water & $5.70 * *(<0.0001)$ & $0.33(0.71)$ & $0.07(0.94)$ \\
\hline Soft sponge (To wipe) & $3.53 *(0.03)$ & $16.43 * *(<0.0001)$ & $-1.51(0.13)$ \\
\hline Cloth (To wipe) & $2.44(0.08)$ & $4.11 *(0.0001)$ & $2.55 *(0.011)$ \\
\hline Air dry & $2.94(0.05)$ & $2.29(0.10)$ & $1.60(0.10)$ \\
\hline Vant & $0.20(0.81)$ & $0.84(0.42)$ & $-0.22(0.82)$ \\
\hline
\end{tabular}

Values in cells are F- value/ t- value with p-value in parenthesis

** significant at $1 \%$ level

* significant at $5 \%$ level

Table.10 Choice of material and kind of lunch box on basis of background

\begin{tabular}{|l|c|c|c|c|c|}
\hline Choice of Material & $\begin{array}{c}\text { Total } \\
(\mathbf{n = 4 8 0})\end{array}$ & Z-value & $\begin{array}{c}\text { Urban } \\
(\mathbf{n = 2 4 0})\end{array}$ & $\begin{array}{c}\text { Rural } \\
(\mathbf{n = 2 4 0})\end{array}$ & $\begin{array}{c}\text { t- value (p } \\
\text { value) }\end{array}$ \\
\cline { 2 - 6 } & Mean \pm SD & & Mean \pm SD & Mean \pm SD & \\
\hline Plastic (Low grade) & $1.48 \pm 1.07$ & $-30.88^{* *}$ & $1.27 \pm 0.66$ & $1.70 \pm 1.32$ & $\begin{array}{c}-4.47^{* *} \\
(<0.0001)\end{array}$ \\
\hline Plastic (Food grade) & $3.9 \pm 1.42$ & $13.80^{* *}$ & $4.16 \pm 1.40$ & $3.63 \pm 1.40$ & $\begin{array}{c}4.09^{* *} \\
(<0.0001)\end{array}$ \\
\hline Stainless Steel & $3.40 \pm 2.38$ & $3.75^{* *}$ & $2.97 \pm 1.60$ & $3.84 \pm 2.90$ & $\begin{array}{c}-4.04^{* *} \\
(<0.0001)\end{array}$ \\
\hline Thermosteel & $2.30 \pm 1.40$ & $10.79^{* *}$ & $2.46 \pm 1.49$ & $2.14 \pm 1.29$ & $\begin{array}{c}2.50^{*} \\
(0.012)\end{array}$ \\
\hline Leakproof & & & & & $-2.76^{* *}$ \\
& $3.39 \pm 1.81$ & $4.76^{* *}$ & $3.16 \pm 1.83$ & $3.62 \pm 1.75$ & $(0.006)$ \\
\hline
\end{tabular}

Mean compared against mid point of the scale i.e 3

** significant at $1 \%$ level

* significant at $5 \%$ level 
Table.11 Choice of material and kind of lunch box on basis of educational Qualification

\begin{tabular}{|c|c|c|c|}
\hline Choice of material & Category & Mean \pm SD & F- value (p value) \\
\hline \multirow[t]{3}{*}{ Plastic (Low grade) } & Upto $12^{\text {th }}$ standard & $1.68^{\mathrm{a}} \pm 1.34$ & \multirow[t]{3}{*}{$3.69 *(0.02)$} \\
\hline & Graduation & $1.37^{\mathrm{bc}} \pm 0.81$ & \\
\hline & Postgraduation & $1.45^{\mathrm{ac}} \pm 1.09$ & \\
\hline \multirow[t]{3}{*}{ Plastic (Food grade) } & Upto $12^{\text {th }}$ standard & $3.82^{\mathrm{a}} \pm 1.30$ & \multirow[t]{3}{*}{$1.73(0.17)$} \\
\hline & Graduation & $4.02^{\mathrm{a}} \pm 1.43$ & \\
\hline & Postgraduation & $3.74^{\mathrm{a}} \pm 1.55$ & \\
\hline \multirow[t]{3}{*}{ Stainless Steel } & Upto $12^{\text {th }}$ standard & $3.87^{\mathrm{a}} \pm 1.39$ & \multirow[t]{3}{*}{$4.71 * *(<0.0001)$} \\
\hline & Graduation & $3.10^{b c} \pm 3.11$ & \\
\hline & Postgraduation & $3.38^{\mathrm{ac}} \pm 1.49$ & \\
\hline \multirow[t]{3}{*}{ Thermosteel } & Upto $12^{\text {th }}$ standard & $2.08^{\mathrm{a}} \pm 1.30$ & \multirow[t]{3}{*}{$4.38 *(0.013)$} \\
\hline & Graduation & $2.30^{\mathrm{ac}} \pm 1.30$ & \\
\hline & Postgraduation & $2.60^{\mathrm{bc}} \pm 1.67$ & \\
\hline \multirow[t]{3}{*}{ Leakproof } & Upto $12^{\text {th }}$ standard & $3.56^{\mathrm{a}} \pm 1.81$ & \multirow[t]{3}{*}{$2.45(0.08)$} \\
\hline & Graduation & $3.44^{\mathrm{a}} \pm 1.74$ & \\
\hline & Postgraduation & $3.07^{\mathrm{a}} \pm 1.90$ & \\
\hline
\end{tabular}

Mean compared against mid point of the scale i.e 3

** significant at $1 \%$ level

* significant at $5 \%$ level

Table.12 Choice of material and kind of lunch box on basis of various parameters

\begin{tabular}{|l|c|c|c|}
\hline \multirow{2}{*}{ Choice of material } & Age & Income & Type f family \\
\cline { 2 - 4 } & F- VALUE & F- VALUE & t- VALUE \\
\hline Plastic (Low grade) & $7.35^{* *}(<0.01)$ & $10.22(0.12)$ & $0.053(0.95)$ \\
\hline Plastic (Food grade) & $6.26 * *(<0.01)$ & $2.10(0.12)$ & $-1.20(0.22)$ \\
\hline Stainless Steel & $0.02(0.97)$ & $1.19(0.30)$ & $0.004(0.99)$ \\
\hline Thermosteel & $1.72(0.18)$ & $5.93 * *(<0.01)$ & $0.63(0.52)$ \\
\hline Leakproof & $0.32(0.72)$ & $1.24(0.29)$ & $0.19(0.84)$ \\
\hline
\end{tabular}

Values in cells are F- value/ t- value with p-value in parenthesis

$* *$ significant at $1 \%$ level

* significant at $5 \%$ level 
Table.13 Correlation of disease incidence with lunch box related practices

\begin{tabular}{|l|c|}
\hline Parameter & \multicolumn{1}{|c|}{ Disease Incidence } \\
\hline Choice of Packaging material & $.191^{* *}$ \\
\hline Paper & $-.098^{*}$ \\
\hline Aluminium foil & $.131^{* *}$ \\
\hline Cloth & $.158^{* *}$ \\
\hline Napkin & $.146^{*}$ \\
\hline Newspaper & \\
\hline Cleaning and drying of lunch boxes & $-.126^{* *}$ \\
\hline Hot water & .083 \\
\hline Cold water & -.089 \\
\hline Detergent & -.066 \\
\hline Soft sponge (To wipe) & $.131^{* *}$ \\
\hline Cloth (To wipe) & -.061 \\
\hline Air dry & \\
\hline Time of cleaning lunch boxes & -.007 \\
\hline Immediately after child came back from school & .064 \\
\hline Evening & .043 \\
\hline Night & $.149^{* *}$ \\
\hline Early morning & \\
\hline Choice of material and kind of lunch box & $.155^{* *}$ \\
\hline Plastic (Low grade) & -.036 \\
\hline Plastic (Food grade) & .059 \\
\hline Stainless Steel & $.138^{* *}$ \\
\hline Thermosteel & -.014 \\
\hline Leakproof & \\
\hline
\end{tabular}

** significant at $1 \%$ level

* significant at $5 \%$ level

Unclean utensils were also considered a source of food contamination. Takanashi et al., (2009) reported that 205 (86.8\%) mothers always washed utensils by water with soap. Silva et al., (2010) evaluated the effectiveness of cleaning and sanitizing procedures in controlling Staphylococcus aureus, Salmonella Enteritidis and Pseudomonas fluorescens adhered to granite and stainless steel.

With regard to microorganisms, S. aureus was the least resistant to the sanitizers. However, a significant difference was observed $(p<0.05)$ between the sanitizer solutions.

Data revealed that educational qualification did not affect the choice of medium for cleaning and drying of lunch boxes as the respondents studied upto $12^{\text {th }}$ standard also preferred to use hot water and air dry method (Table 8 ). The postgraduates preferred to use cold water (mean score: 3.91 ) and soft sponge (mean score: 4.50) to clean lunch boxes. The $12^{\text {th }}$ standard respondents used the hot water (mean score: 3.54 ), practiced to use cloth to wipe (mean score: 3.87 ) and air dry method with a mean score of 3.95 and a significant $(p<0.01)$ difference was found among the 
mean scores given by the respondents. Food handlers with good knowledge and practices reduce contamination risk of food utensils. Some bacteria survive on food utensils if cleaning and sanitizing are ineffective (Cosby et al., 2008).The presence of bacteria is an indicator of food utensils' cleanliness level (Lues and Tonder, 2007). Logistic regression statistical analysis showed that respondents with insufficient knowledge influence presence of total coliform on knives 0.4 times more compared to respondents that have sufficient knowledge $(95 \% \mathrm{CI}=0.16,0.95)$ (Saipullizan et al., 2018).

The respondents were enquired about the practices related to cleaning and drying of lunch boxes on the basis of various parameters like age, income and type of family in Table 9. Data revealed that the respondents in age group of 30- 39 years, belonging to income category of above Rs. 5 lakhs preferred to use hot water and air dry method to clean the lunch boxes. So, the age, income and type of family affected the adoption of practices related to cleaning and drying of lunch boxes. Saipullizan et al., (2018) reported that respondents (76.9\%) knew that use of dirty dish cloths increased the risk of food contamination. Proper cloth materials to wipe food utensils are important because bacteria can cross contaminate from a dirty surface to a clean one (Koo et al., 2013).

\section{Type of lunch box}

The data regarding the usage of material and kind of lunch boxes preferred by the respondents was presented in Table 10. It can be observed from the table that Food grade plastic was the most preferred material with the mean score of 3.9 preferably used by the urban respondents, followed by the stainless steel having mean score of 3.40. Further data showed that thermosteel (mean score: 2.30) and leak proof (mean score: 3.39 ) lunch boxes was mostly used by the urban respondents. For the practice of using thermosteel, the significant difference was found across the various groups made on the basis of background $(\mathrm{p}<0.01)$. The lunch boxes made up of Low grade plastic was given least score of 1.48 with a significant difference $(p<0.01)$ between the mean scores given by urban and rural.

The data regarding the usage of material and kind of lunch boxes by the respondents categorized on the basis of educational qualification is showed in Table 11. It can be observed from the table that higher the educational qualification better was the choice of lunch box material. As it can be seen from the table that graduate and postgraduate respondents preferred Food grade plastic and thermosteel with a mean score of 4.02 and 2.60. Further data showed that low grade plastic and stainless steel was more preferred by the respondents studied upto $12^{\text {th }}$ standard with the mean score of 1.68 and 3.87 .

The data regarding the choice of material and kind of lunch boxes was further compared on the basis of age, income and type of family of the respondents in table 12. It can be observed from the table that respondents in the age group of 20-29 years, belonging to the income category of above Rs 5 Lakhs, belonging to joint families preferred to use food grade plastic and stainless steel. Hussain et al., (2015) reported that low grade plastic contain more amount of bisphenol $\mathrm{A}$ which is a toxic chemical and is hazardous for health of children.

\section{Relation between Lunch Boxes related Practices and Incidence of Disease}

For the purpose of finding out the relation between lunch box related practices and incidence of food borne diseases correlation analysis was used. Results obtained from the 
correlation analysis have been presented in Table 13. It can be seen from the table that for all the respondents included in the study, the practice of use of aluminium foil showed a significant $(\mathrm{p}<0.05)$ negative correlation with the disease incidence. A significant positive correlation was observed between the disease incidence and the practice of using paper $(\mathrm{p}<0.01)$, cloth napkin $(\mathrm{p}<0.01)$, paper napkin $(p<0.01)$ and newspaper $(0.05)$ for packing of chapattis in children's packed lunch. This means with the increase in the use of paper or newspaper for wrapping commodities in Lunch Box there was also an increase in the disease incidence scores whereas use of Aluminium foil in context of microbial load is considered as a safe option for wrapping of food commodity in Lunch boxes. From the cleaning practices it was found that the respondents who prefer hot water for cleaning of lunch box showed a negative significant correlation $(\mathrm{p}<0.01)$ with the disease incidence scores. Also the practice of use of soft sponge and air dry method to clean lunch boxes showed a negative correlation with the disease incidence score. It can be concluded that the use of hot water, soft sponge and air dry method can reduce the microbial count in the Lunch boxes which lowers the risk of pathogenic diseases in children.

\section{Also a significant $(\mathrm{p}<0.01)$ positive} correlation was found between the practice of using cloth to wipe lunch boxes with the disease incidence score as several studies have documented the common occurrence of large populations of heterotrophic and enteric bacteria in kitchen dishcloths where the moist environment and collected food residues create an ideal environment for the growth of bacteria (Charles et al., 2014) and this was supported by Enriquez et al., (1996) who found total and fecal coliform bacteria in large numbers in dishcloths and Salmonella spp. was isolated from almost $14 \%$ of the dishcloths. It was also observed that the respondents who prefer to clean the lunch box in the early morning have a significant $(p<0.01)$ positive correlation with the disease incidence score. The practice of cleaning lunch boxes immediately after child came back from school showed a negative correlation with the disease incidence as cleaning lunch boxes immediately after child came back from school lead to lower microbial load as compared to cleaning it early morning. Also a positive significant $(p<0.01)$ correlation was observed between the disease incidence score and the use of low grade plastic and thermosteel lunchboxes. There is growing evidence that food can be contaminated by harmful chemicals from some type of plastics. Thus the use of high grade plastic and steel is a better option.

Results revealed that regarding the choice of packaging material it was seen that in both urban and rural respondents aluminium foil was the most preferred packaging material. This was followed by cloth napkin, paper napkin and newspaper. Most of the respondents preferred evening time to clean lunch boxes. Food grade plastic was the most preferred material preferably used by the urban respondents, followed by the stainless steel and Low grade plastic. Further data revealed that various demographic parameters of respondents had significant effect on the practices related to children's packed lunch boxes. The results revealed that the practice of use of aluminium foil, cleaning lunch boxes with hot water, soft sponge and air dry method, cleaning lunch boxes immediately after child came back from school showed a significant negative correlation with the disease incidence. A significant positive correlation was observed between the disease incidence and the practice of using paper, cloth napkin, paper napkin and newspaper for packing of chapattis in children's packed lunch, practice of using cloth to wipe lunch boxes, cleaning lunch box in the early 
morning, and the use of low grade plastic and thermo steel lunchboxes.

\section{Recommendation}

Aluminium foil is better packaging material in context of microbial load. Newspapers and paper napkins should not be used as packaging material.

Preferred material for lunch box should be stainless steel or High grade plastic.

Washing of lunch box using hot water and detergent should be done immediately after child came back home.

\section{References}

Ahmed WAM (2015) Mothers' Knowledge Regarding Preventive Measures of Food Poisoning in Yemen. Food Nutr Sci 6: 49-53.

Almansour F, Sweitzer S, Magness A, Calloway E, McAllaster M, Roberts G C, Hoelscher D and Briley M (2011) Temperature of foods sent by parents of preschool-aged children. Pediatr 128: 519-23.

Charles P G, Akrum HT, Sherri M, Laura YS, Douglas R H and David W K (2014) Bacterial occurrence in Kitchen Hand Towels. Food Protec Trends 34: 31217.

Cosby CM, Costello CA, Morris WC, Haughton B, Devereaux M J and Harte F (2008) Microbiological analysis of food contact surfaces in child care centers. Appl Environ Microbiol 74: 6918-22.

Emily Thackston (2013) "The effect of packaging material properties on consumer food quality perception in quick-service restaurants". All Theses. 1673.

Enriquez C E R, Enriquez G, Kennedy D I and Gerba CP (1996) Bacteriological survey of used cellulose sponges and dishcloths from domestic kitchens. Dairy, Food Environ Sanit 17: 20-24.

Erickson MC, Jennifer JL and Ortega CY (2015) Contamination of knives and graters by bacterial foodborne pathogens during slicing and grating of produce. Food Microbiol 52: 138-45.

Griffin T L and Barker M E (2008) Packed lunches for primary-school children: A qualitative study of parents' views. Proc Nutr Soc 67: 218.

Hughes C, Gillespie I and O'Brien S (2007) Breakdowns in Food Safety Group. Food- borne transmission of infectious intestinal disease in England and Wales, 1992-2003. Food Ctrl 18: 766-72

Husain I, Alalyani M, Hanga AH (2015) Disposable Plastic Food Container and Its Impacts on Health. The Journal of Energy and Environmental Science. Photon 130: 618-23

Koo O K, Martin EM, Story R, Lindsay D, Ricke S C and Crandal P G (2013) Comparison of cleaning fabrics for bacterial removal from food-contact surfaces. Food Ctrl 30: 292-97.

Kwun H Y, Kim J H and Lee H M (2011) Beneficiaries' Satisfaction, Menu Preference and Dietary Habits of Lunch-box Program Provided to Lowincome Families. Korean J Food Nutr 24: $320-28$.

Lues JFR and Tonder V I (2007) The occurrence of indicator bacteria on hands and aprons of food handlers in the delicatessen sections of a retail group. Food Ctrl 18: 326-32.

Ogba I E and Johnson R (2010) How packaging affects the product preferences of children and the buyer behaviour of their parents in the food industry. Young Consumers: Insight and Ideas for Responsible Marketers 11: 7789. 
Roberts K R, Barrett BB, Howells AD, Shanklin CW, Pilling V K and Brannon LA (2008) Food safety training and foodservice employees' knowledge and behavior. Food Protec Trends 28: 25260.

Saipullizan S N, Mutalib S and Sedek R (2018) Knowledge, Attitude and Practice of Food Utensils Hygiene amongst Food Handlers in Kuala Pilah, Negeri Sembilan, Malaysia. Sains Malaysiana 47: 1527-33.

Silva DIC, Torres R, Capua J L and Andrade N J (2010) Effectiveness of cleaning and sanitizing procedures in controlling the adherence of Pseudomonas fluorescens, Salmonella enteritidis, and Staphylococcus aureus to domestic kitchen surfaces. Food Sci Technol 30: 231-36.

Silva DIC, Torres R, Capua J L and Andrade N J (2010) Effectiveness of cleaning and sanitizing procedures in controlling the adherence of Pseudomonas fluorescens, Salmonella Enteritidis, and Staphylococcus aureus to domestic kitchen surfaces. Food Sci Technol 30: 231-36.

Takanashi K, Chonan Y, Quyen DT, Khan NC, Poudel KC and Jimba M (2009) Survey of Food-hygiene Practices at Home and Childhood Diarrhoea in Hanoi, Viet Nam. J Hlth Popul Nutr 27: 602-11.

U.S. Department of Agriculture Food and Nutrition Service (2012) Nutrition standards in the National School Lunch and School Breakfast Program, Final Rule. Washington, DC: Federal Register

U.S. Department of Agriculture Food Safety and Inspection Service (2005) A report of the "Is It Done Yet?" social marketing campaign to promote the use of food thermometers. http://www.fsis.usda.gov/PDF/IsItDone Yet_Campaign_Report_120105.pdf. Retrieved 10.06.12.

\section{How to cite this article:}

Sloney Sachar and Sonika Sharma. 2019. Protecting Child Health by Preventing School Packed Lunch Related Food Borne Illnesses: A Qualitative Study of Parents Lunch Box Related Practices. Int.J.Curr.Microbiol.App.Sci. 8(08): 1920-1933. doi: https://doi.org/10.20546/ijcmas.2019.808.226 